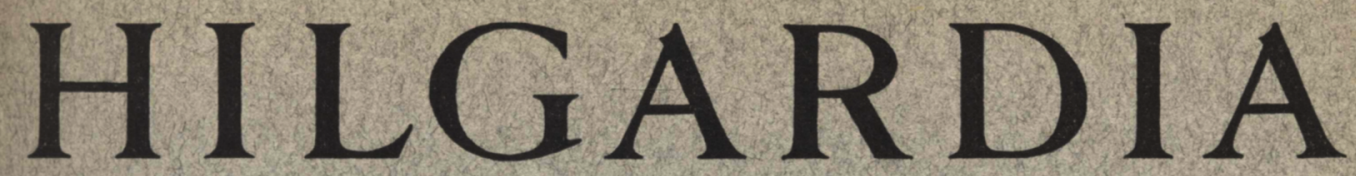

A Journal of Agricultural Science Publisbed by the California Agricultural Experiment Station

\title{
CONTENTS
}

\section{FACTORS AFFECTING THE RECOVERY OF HYDROCYANIC ACID FROM FUMIGATED CITRUS TISSUES}

\author{
E. T. BARTHOLOMEW, WALTON B. SINCLAIR, \\ and BYRON E. JANES
}




\title{
$\begin{array}{lllllllll}H & \text { I } & \text { L } & G & \text { A } & \text { R } & \text { D } & \text { I } & \text { A }\end{array}$
}

A Journal of Agricultural Science Published by

the California Agricultural Experiment Station

\section{FACTORS AFFECTING THE RECOVERY OF HYDROCYANIC ACID FROM FUMIGATED CITRUS TISSUES ${ }^{1,2}$}

\author{
E. T. BARTHOLOMEW, ${ }^{3}$ WALTON B. SINCLAIR, ${ }^{4}$ \\ AND BYRON E. JANES ${ }^{5}$
}

UNDER CERTAIN conditions of fumigation for scale insects of citrus trees, hydrocyanic acid ( $\mathrm{HCN})$ is known to cause injury to the foliage and fruit. The physiological reactions involved in the injury have received but slight quantitative investigation. Undoubtedly the reasons for this have been the difficulties encountered in distilling $\mathrm{HCN}$ from materials containing volatile substances which are reactive with $\mathrm{HCN}$. The lack of a method with sufficient accuracy to recover relatively small amounts of HCN from the tissues may also have been an important factor.

The results reported in this paper are concerned only with the factors affecting the distillation and recovery of $\mathrm{HCN}$ from solutions in the absence of tissues and also in the presence of citrus foliage and fruits. Earlier attempts to recover HCN from fumigated citrus tissues by aspiration, partial vacuum, immersing and shaking the tissues in an alkaline solution, or by a combination of these processes have given unsatisfactory results. All statements in this paper concerning the recovery of $\mathrm{HCN}$ from citrus tissues refer to $\mathrm{HCN}$ added by fumigation or by other methods. Repeated tests by Bartholomew and Raby (3) and in the present investigation have shown that citrus tissues do not contain autogenous $\mathrm{HCN}$.

An investigation is being made of the physiological effects of $\mathrm{HCN}$ in citrus tissues.

\footnotetext{
${ }^{1}$ Received for publication October 7, 1938.

${ }^{2}$ Paper No. 390, University of California Citrus Experiment Station and Graduate School of Tropical Agriculture, Riverside, California.

${ }^{3}$ Plant Physiologist in the Experiment Station.

${ }^{4}$ Junior Plant Physiologist in the Experiment Station.

- Laboratory Assistant in Plant Physiology in the Experiment Station.
} 


\section{THE QUANTITATIVE DETERMINATION OF HCN IN THE ABSENCE OF CITRUS TISSUES}

A modified Liebig silver-nitrate-volumetric method was employed for the determination of $\mathrm{HCN}$, the end points of titration being determined by the use of a photoelectric turbidimeter. The operations were conducted according to the recommendations made by Bartholomew and Raby $(2,3)$. Preliminary experiments, however, demonstrated that a new method of recovery of HCN must be developed or an old one be adapted to the material to be investigated.

Considerable difficulty was experienced in weighing accurately such small amounts of liquid HCN as were being used. The first method was

TABLE 1

Amounts of HCN Recovered From Known Quantities of NaCN Dissolved in $0.1 \mathrm{~N} \mathrm{NaOH}$ Solutions

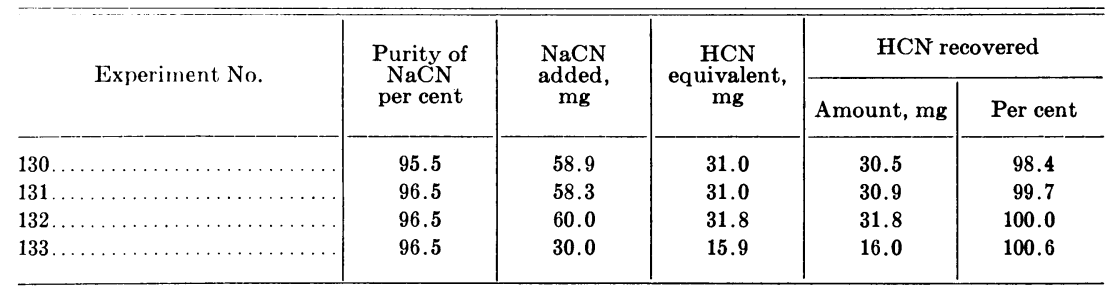

to seal 30 to $40 \mathrm{mg}$ of liquid $\mathrm{HCN}$ in a weighed 5 -ml glass ampoule. When the ampoule was broken in a liter of $0.1 \mathrm{~N} \mathrm{NaOH}$ and 150-ml aliquots titrated with standard $\mathrm{AgNO}_{3}$, the total amount of $\mathrm{HCN}$ determined was 104 to 106 per cent of the quantity originally weighed. The possible sources for this error were in the method of titration and in the method of weighing the liquid HCN. The results recorded in table 1, which show the recovery of $\mathrm{HCN}$ from $\mathrm{NaCN}$, demonstrated that the titration method was accurate.

This left as the only other source of error, the inaccurate method of weighing : if a small amount of liquid HCN $(30-40 \mathrm{mg})$ is placed in a weighed 5-ml ampoule and a second weighing is made, the difference between the two weights does not show the exact amount of HCN in the ampoule because a certain amount of the air is replaced by HCN vapor, which is lighter. ${ }^{\circ}$ The actual amount of air displacement in the larger

\footnotetext{
" For example, at $23^{\circ} \mathrm{C}$ and $750-\mathrm{mm}$ pressure and with a difference of $31 \mathrm{mg}$ between the first and second weighings, the ampoule (5-ml capacity) would contain an excess of 19 per cent of HCN if all the air $(5.9 \mathrm{mg})$ were displaced. Liquid HCN has a low boiling point $-26^{\circ}$-and an exceedingly high vapor pressure at ordinary laboratory temperatures-654.4 $\mathrm{mm}$ at $22^{\circ}(9)$.
} 
containers could not be governed or determined; therefore the amount of $\mathrm{HCN}$ existing in the vapor phase was reduced to a minimum by using ampoules with a volume just equivalent to, or only slightly greater than, the amount of liquid HCN desired for a given test. This eliminated the difficulty.

The quantities of $\mathrm{HCN}$ used in the experiments were small, never over $100 \mathrm{mg}$, the average amount being about $39 \mathrm{mg}$. The laboratory fumigation chamber has a capacity of 5 liters, and the total volume of the solu-

TABLE 2

Amounts of HCN Recovered after Various Treatments

\begin{tabular}{|c|c|c|c|c|}
\hline \multirow{2}{*}{$\begin{array}{l}\text { Treatment } \\
\text { (liquid HCN used) }\end{array}$} & \multirow{2}{*}{$\begin{array}{l}\text { Experiment } \\
\text { No. }\end{array}$} & \multirow{2}{*}{$\underset{\mathrm{mg}}{\mathrm{HCN} \text { added, }}$} & \multicolumn{2}{|c|}{$\mathrm{HCN}$ recovered } \\
\hline & & & Amount, mg & Per cent \\
\hline \multirow{4}{*}{$\begin{array}{l}\text { A, In empty fumigation flask } 45 \text { min., then } \\
\text { acidulated } \mathrm{H}_{2} \mathrm{O} \text { and } \mathrm{CdSO}_{4} \text { added } \ldots\end{array}$} & 163 & 41.6 & 41.2 & 99.0 \\
\hline & 165 & 23.5 & 23.5 & 100.0 \\
\hline & 166 & 33.9 & 33.9 & 100.0 \\
\hline & 167 & 11.0 & 11.0 & 100.0 \\
\hline \multirow{6}{*}{ B, In $0.1 N \mathrm{NaOH}$ without distillation........ } & 146 & 897.9 & 901.0 & 100.3 \\
\hline & 147 & 16.7 & 17.0 & 101.8 \\
\hline & 148 & 22.0 & 21.8 & 99.1 \\
\hline & 149 & 44.2 & 44.4 & 100.5 \\
\hline & 150 & 28.6 & 29.3 & 102.4 \\
\hline & 153 & 53.2 & 53.5 & 100.6 \\
\hline \multirow{2}{*}{$\begin{array}{l}\mathrm{C} \text {, In } 0.1 \mathrm{~N} \mathrm{NaOH} \text { with double distillation, } \\
\text { acidulated } \mathrm{H}_{2} \mathrm{O} \text { and } \mathrm{CdSO}_{4} \text { added } \ldots \ldots\end{array}$} & 218 & 33.7 & 33.5 & 99.4 \\
\hline & 219 & 26.1 & 25.8 & 98.9 \\
\hline
\end{tabular}

tions used for distillation was 3 liters. As shown by these volumes, the actual concentrations of $\mathrm{HCN}$ used in the experiments were very low. Before the experimental methods could be applied to citrus tissues, the conditions for the distillation and recovery of pure samples of $\mathrm{HCN}$ in such concentrations had to be standardized.

Having solved the difficulties previously encountered in weighing known amounts of $\mathrm{HCN}$, the first step in standardizing the methods for its recovery was to break the ampoule of liquid $\mathrm{HCN}$ in the empty fumigation flask and allow it to remain for 45 minutes. Thirty grams of $\mathrm{CdSO}_{4}$ were added and enough $\mathrm{H}_{2} \mathrm{SO}_{4}$ in each case to make the solution slightly acid- 0.15 or $0.30 \mathrm{ml}$ beyond neutrality (p. 477), according to the nature of the solution to be distilled. (The reason for adding the $\mathrm{CdSO}_{4}$ will be explained in the following section.) The results of these tests demonstrated that no losses occurred through the apparatus connections. The tabulated results are shown as treatment $\mathrm{A}$ in table 2.

The second step was to break ampoules containing known amounts of 
liquid $\mathrm{HCN}$ in the bottom of a tall cylinder containing about $900 \mathrm{ml}$ of $0.1 \mathrm{~N} \mathrm{NaOH}$. The solution was then poured into a liter volumetric flask and diluted to volume. The solution was not distilled; therefore no acid or $\mathrm{CdSO}_{4}$ was added. Aliquot samples of $150 \mathrm{ml}$ each were titrated with standard $\mathrm{AgNO}_{3}$. The amounts recovered were in agreement with the available amount in each sample, as shown for treatment $B$ in table 2.

The third step was to attempt to recover the $\mathrm{HCN}$ from $0.1 \mathrm{~N} \mathrm{NaOH}$ by double distillation, after having added the usual amounts of $\mathrm{H}_{2} \mathrm{SO}_{4}$ and $\mathrm{CdSO}_{4}$. The first distillates were redistilled because, as explained elsewhere in this paper, the first distillate from fumigated leaves contained a volatile substance which interfered with the titration of the $\mathrm{HCN}$. The data (treatment $\mathrm{C}$ in table 2) show that the double distillation process resulted in only a very slightly lower percentage recovery of $\mathrm{HCN}$ than treatment B.

\section{THE RECOVERY OF HCN FROM CITRUS-LEAF DISTILLATES}

General Methods with Leaves.-Mature or young citrus leaves were picked from the trees, placed in a container with a tight cover, and immediately brought to the laboratory and thoroughly mixed. About 15 to 20 minutes elapsed between picking the leaves and placing them in the fumigation flask. The moisture in each lot of leaves was determined on a 100 -gram sample by heating the leaves at $100^{\circ} \mathrm{C}$ for 1 hour and then to constant weight at $70^{\circ}$. The loss in weight was recorded as the percentage of moisture.

Unless otherwise stated, 200 grams of mature leaves were used for each fumigation experiment. The 200-gram sample was fumigated in a 5-liter Pyrex flask and the length of the fumigation period was always 45 minutes unless otherwise stated. Pyrex flasks were used in place of ordinary soda flasks because sodium cyanide would have been formed on the walls of the latter (9). A small ampoule containing a known amount of HCN was broken in the flask containing the leaves. The flask was closed with a rubber stopper containing a large glass tube and a separatory funnel, both of which contained stopcocks so that an airtight seal could be made and no appreciable loss of $\mathrm{HCN}$ would occur. Tin foil was firmly cemented to the lower surface and sides of the stopper so that no reaction could take place between the rubber and the HCN (5). The flask was kept in an inverted position and shaken several times during the fumigation period.

At the end of the fumigation period, the flask was connected to a condenser by means of the large glass tube. The end of the condenser extended to the bottom of a 1-liter volumetric flask containing $100 \mathrm{ml}$ of 
$N \mathrm{NaOH}$. The large stopcock in the tube leading to the condenser was opened, and 3 liters of acidulated distilled water was added through the separatory funnel. Enough material was distilled over to make 1 liter in the receiving flask; this brought the distillate to approximately $0.1 \mathrm{~N}$ with respect to $\mathrm{NaOH}$. After the distillate had been filtered, 2 liters of acidulated distilled water and 30 grams of $\mathrm{CdSO}_{4}$ were added, and another liter distilled and caught as before. Aliquots of $150 \mathrm{ml}$ each of the second distillate were titrated to turbidity with standard $\mathrm{AgNO}_{3}$. The concentration of the $\mathrm{AgNO}_{3}$ was usually $0.020 \mathrm{~N}$, but ranged from 0.019 to $0.022 N$.

The amount of acid placed in the distillation flask depended on whether it was added directly to the fumigated tissues or to the alkaline distillate. In the earlier tests, $0.2666 \mathrm{~N}$ (2 per cent) tartaric acid or $0.0036 \mathrm{~N} \mathrm{H}_{2} \mathrm{SO}_{4}$ ( $0.30 \mathrm{ml}$ of concentrated $\mathrm{H}_{2} \mathrm{SO}_{4}$ in 3 liters of solution) beyond the calculated neutrality (of solutions) was used. Before the investigation had progressed very far, citrus tissues were found to be sufficiently acid in reaction to make possible the recovery of the $\mathrm{HCN}$ during the distillation process. Therefore during the later tests on the leaves and on all of the fruits, only $0.0018 \mathrm{~N} \mathrm{H}_{2} \mathrm{SO}_{4}(0.15 \mathrm{ml}$ in 3 liters of solution) was added. This precaution was taken to make sure that the medium would be acid in all cases.

Interference of Hydrogen Sulfide.-Difficulties were encountered at once when attempts were made to determine $\mathrm{HCN}$ in the distillate from fumigated leaves. The first experiments showed that the distillate contained volatile substances which were carried over with the steam and which produced a darkening of the distillate on the addition of the first increment of $\mathrm{AgNO}_{3}$. Continued darkening of the solutions with further additions of $\mathrm{AgNO}_{3}$ made it obvious that $\mathrm{HCN}$ could not be determined in the presence of such impurities. Therefore the immediate problem was to free the distillate of the volatile substances which reacted with $\mathrm{AgNO}_{3}$.

There are from 2 to $4 \mathrm{ml}$ of volatile oils in a liter of distillate from a 200-gram sample of leaves. The removal of most of the oil by filtration did not eliminate the titration difficulties. Quantitative tests showed that the distillate was free of organic sulfur and volatile nitrogenous compounds. The solution, however, had a slight odor of $\mathrm{H}_{2} \mathrm{~S}$, the actual presence of which was confirmed by testing with lead acetate.

A quantitative determination of the $\mathrm{H}_{2} \mathrm{~S}$ was made by the $\mathrm{CdSO}_{4}$ method, as described by Scott (8). A 200-gram sample of leaves was distilled and four successive portions of $200 \mathrm{ml}$ each were caught in $50 \mathrm{ml}$ of a 6 per cent solution of $\mathrm{CdSO}_{4}$. Separate similar distillations were made with the whole fruit, peel, and pulp. As shown in table 3, the total amount 
of $\mathrm{H}_{2} \mathrm{~S}$ which occurred in the distillate from the leaves or fruit was relatively small. However, when an aliquot portion was titrated with $\mathrm{AgNO}_{3}$, the quantity of $\mathrm{Ag}_{2} \mathrm{~S}$ formed was sufficient to discolor the solution to such an extent that a false end point was obtained.

The problem at hand was to convert the volatile $\mathrm{H}_{2} \mathrm{~S}$ to a compound which was neither volatile with steam nor reactive with $\mathrm{HCN}$. In an effort to do this, $\mathrm{CdSO}_{4}$ was added just before distillation began. The $\mathrm{H}_{2} \mathrm{~S}$ reacted with the $\mathrm{CdSO}_{4}$ to form CdS, which is nonvolatile and which remained in the flask during distillation. To convert all the $\mathrm{H}_{2} \mathrm{~S}$ to CdS,

TABLE 3

A mounts of Volatile $\mathrm{H}_{2} \mathrm{~S}$ ObTained From the Distillates of Citrus Leaves and Green Fruits

\begin{tabular}{|c|c|c|c|c|c|c|c|}
\hline \multirow{2}{*}{$\begin{array}{l}\text { Fraction } \\
\text { (distillate) No., } \\
200 \mathrm{ml} \text { each }\end{array}$} & \multicolumn{4}{|c|}{$\begin{array}{c}\mathrm{H}_{2} \mathrm{~S} \text { from } 200-\mathrm{gm} \text { samples of } \\
\text { leaves, mg }\end{array}$} & \multicolumn{3}{|c|}{$\begin{array}{l}\mathrm{H}_{2} \mathrm{~S} \text { from } 15 \text { green Valencia } \\
\text { oranges, } \mathrm{mg}\end{array}$} \\
\hline & Sample I & Sample II & Sample III & Sample IV & Whole fruit & Peel & Pulp \\
\hline $1 \ldots \ldots \ldots \ldots \ldots$ & 2.28 & 2.38 & 2.20 & 2.29 & 3.40 & 1.32 & 1.41 \\
\hline $2 \ldots \ldots \ldots \ldots \ldots$ & 0.73 & 0.82 & 0.64 & 0.64 & 0.75 & 0.99 & 0.58 \\
\hline $3 \ldots \ldots \ldots \ldots \ldots \ldots$ & 0.55 & 0.55 & 0.46 & 0.55 & 0.66 & 0.66 & 0.58 \\
\hline $4 \ldots \ldots \ldots \ldots$ & 0.46 & $\ldots$ & 0.55 & 0.46 & 0.75 & 0.50 & 0.66 \\
\hline Total... & 4.02 & 3.75 & 3.85 & 3.94 & 5.56 & 3.47 & 3.23 \\
\hline
\end{tabular}

however, the solution would have had to cover the leaves entirely during distillation. This was impossible because the specific gravity of the fresh leaves was less than that of the solution; hence, the $\mathrm{CdSO}_{4}$, instead of being placed in the flask with the leaves, was placed in the leaf distillate, and this solution was redistilled. The double distillation process freed the solution of all $\mathrm{H}_{2} \mathrm{~S}$.

Before applying this procedure to leaves, it was necessary to determine experimentally what effect, if any, $\mathrm{CdSO}_{4}$ would have on the recovery of known amounts of HCN. This was done by breaking ampoules containing known amounts of $\mathrm{HCN}$, in $0.1 \mathrm{~N} \mathrm{NaOH}$. This solution was then poured into the distilling flask and diluted to 3 liters. In some of the experiments $\mathrm{H}_{2} \mathrm{SO}_{4}$, and in others tartaric acid, was used. Each distillation was made in the presence of 30 grams of $\mathrm{CdSO}_{4}$. The results given in table 4 show that the presence of the $\mathrm{CdSO}_{4}$ did not materially reduce the percentage of recovery of $\mathrm{HCN}$, and that the recoveries were the same with $\mathrm{H}_{2} \mathrm{SO}_{4}$ and with tartaric acid.

Penetration of HCN into Leaf Tissues.-A series of experiments was carried out to determine the amount of $\mathrm{HCN}$ that actually penetrated the leaves during fumigation. At the end of the fumigation period, the 
leaves were washed in the 5-liter fumigation flask with 2 liters of $0.1 \mathrm{~N}$ $\mathrm{NaOH}$ by shaking thoroughly so as to get the alkaline solution to contact the walls of the flask and the surface of the leaves. The leaves were then washed four times with distilled water, 2 liters each time, and finally with 2 liters of acidulated water (containing $0.15 \mathrm{ml}$ of concentrated $\mathrm{H}_{2} \mathrm{SO}_{4}$ ). The acid solution was poured from the leaves, then 3 liters of the acidulated water was added to the leaves in the flask and distillation conducted in the usual manner.

TABLE 4

Amounts of HCN Recovered AFTER Distillation From Solutions ACidified WITH $\mathrm{H}_{2} \mathrm{SO}_{4}$ OR TARTARIC ACID

(Each solution contained 30 grams $\mathrm{CdSO}_{4}$ )

\begin{tabular}{|c|c|c|c|c|}
\hline \multirow{2}{*}{ Acid used } & \multirow{2}{*}{$\begin{array}{l}\text { Experiment } \\
\text { No. }\end{array}$} & \multirow{2}{*}{$\underset{\mathrm{mg}}{\mathrm{HCN} \text { added }}$} & \multicolumn{2}{|c|}{$\mathrm{HCN}$ recovered } \\
\hline & & & Amount, mg & Per cent \\
\hline \multirow{6}{*}{$\mathrm{H}_{2} \mathrm{SO}_{4}$.. } & 151 & 26.1 & 26.2 & 100.4 \\
\hline & 152 & 38.9 & 39.0 & 100.3 \\
\hline & 155 & 34.3 & 34.5 & 100.6 \\
\hline & 154 & 29.6 & 30.1 & 101.7 \\
\hline & 161 & 28.8 & 28.7 & 99.7 \\
\hline & Average & $\ldots$ & $\cdots$ & 100.5 \\
\hline \multirow{5}{*}{ Tartaric acid. . } & 156 & 53.4 & 53.6 & 100.4 \\
\hline & 157 & 18.4 & 18.6 & 101.1 \\
\hline & 158 & 59.9 & 60.0 & 100.2 \\
\hline & 160 & 32.3 & 32.5 & 100.6 \\
\hline & Average & $\ldots$ & $\ldots$ & 100.6 \\
\hline
\end{tabular}

As may be seen in table 7 (p. 481) an average recovery of 66.3 per cent of the HCN added was obtained from the different lots of leaves which had received such a washing treatment in the interval between fumigation and distillation.

Retention and Fixing of $H C N$ by the Tissues.-Another experiment was made to determine how much available $\mathrm{HCN}$ had remained in the leaves at given intervals after fumigation. The leaves were treated and recoveries made according to the procedure already described. At the end of the 45-minute fumigation period, the leaves were removed from the chamber, spread on $1 / 4$-inch-mesh wire screen and exposed to laboratory air for 1 minute, and for periods of 2, 4, 8, and 15 hours before they were distilled for the determination of HCN.

The results of these experiments are shown in table 5. A measurable amount of $\mathrm{HCN}$ remained in the leaves even after an exposure of 15 hours to the laboratory air. The HCN that could not be recovered was apparently fixed in the vapor phase or by some nonvolatile substance in the leaf tissues either before or during distillation. 
In order to determine whether the reactions occurred entirely or at least largely in the vapor phases, known amounts of $\mathrm{HCN}$ were added to distillates from unfumigated leaves and distilled at once in the usual manner. The results of these tests, given in table 6 , show an average recovery of 99.0 per cent of the HCN.

TABLE 5

Amounts of HCN Recovered from Five 200-Gram Lots of Citrus Leaves Exposed to Laboratory Air for Different Lengths of Time after Fumigation

\begin{tabular}{|c|c|c|c|c|c|}
\hline \multirow{2}{*}{ Time aerated } & \multirow{2}{*}{$\begin{array}{l}\text { Experiment } \\
\text { No. }\end{array}$} & \multirow{2}{*}{$\begin{array}{c}\text { Moisture } \\
\text { in } \\
\text { leaves, } \\
\text { per cent }\end{array}$} & \multirow{2}{*}{$\begin{array}{c}\mathrm{HCN} \\
\text { added, mg }\end{array}$} & \multicolumn{2}{|c|}{$\mathrm{HCN}$ recovered } \\
\hline & & & & $\underset{\mathrm{mg}}{\text { Amount, }}$ & Per cent \\
\hline \multirow{5}{*}{1 minute... } & 237 & 56.2 & 48.2 & 29.1 & 60.4 \\
\hline & 238 & 60.1 & 34.7 & 23.0 & 66.3 \\
\hline & 241 & 57.0 & 38.7 & 28.3 & 73.1 \\
\hline & 242 & 55.7 & 49.6 & 33.5 & 67.5 \\
\hline & Average & $\ldots$ & $\ldots$ & $\ldots$ & 66.8 \\
\hline \multirow{5}{*}{2 hours. . } & 222 & 59.5 & 47.3 & 17.5 & 37.0 \\
\hline & 223 & 58.3 & 33.0 & 13.1 & 39.7 \\
\hline & 225 & 59.0 & 44.0 & 16.8 & 38.2 \\
\hline & 227 & 56.6 & 37.2 & 14.6 & 39.2 \\
\hline & Average & $\cdots$ & $\ldots$ & $\ldots$ & 38.5 \\
\hline \multirow{5}{*}{4 hours. } & 251 & 54.8 & 28.4 & 7.8 & 27.5 \\
\hline & 252 & 54.8 & 28.9 & 8.6 & 29.8 \\
\hline & 264 & 59.1 & 31.2 & 8.3 & 26.6 \\
\hline & 265 & 59.1 & 27.8 & 7.1 & 25.5 \\
\hline & Average & $\ldots$ & $\ldots$ & $\ldots$ & 27.4 \\
\hline \multirow{5}{*}{8 hours. . } & 266 & 58.0 & 40.2 & 6.3 & 15.7 \\
\hline & 267 & 58.0 & 34.2 & 4.6 & 13.5 \\
\hline & 268 & 59.0 & 32.0 & 4.4 & 13.8 \\
\hline & 269 & 59.0 & 43.0 & 6.3 & 14.7 \\
\hline & Average & $\ldots$ & $\ldots$ & $\ldots$ & 14.4 \\
\hline \multirow{5}{*}{15 hours... } & 230 & 58.5 & 37.2 & 7.6 & 20.4 \\
\hline & 231 & 57.9 & 28.1 & 4.7 & 16.7 \\
\hline & 239 & 57.3 & 31.2 & 4.2 & 13.5 \\
\hline & 240 & 60.4 & 44.0 & 4.1 & 9.3 \\
\hline & Average & $\ldots$ & $\ldots$ & $\ldots$ & 15.0 \\
\hline
\end{tabular}

The next point was to determine whether additional $\mathrm{HCN}$ would react and combine with nonvolatile substances in the leaf tissues or with substances that were not volatile enough to be carried over during the first distillation. (Previous tests had shown that additional amounts of volatile substances were driven over when leaf tissues were distilled a second time.) For this purpose, known amounts of $\mathrm{HCN}$ were added to different 200-gram lots of unfumigated leaves and distilled at once. The results of these tests, also given in table 6 , show an average recovery of only 95.8 per cent of the HCN. 
TABLE 6

Recovery of HCN That Had Been Added Directly to the Distillates from Citrus Leaves and Then Distilled or That Had Been Distilled in the Presence of Mature Citrus Leaves

\begin{tabular}{|c|c|c|c|c|c|}
\hline \multirow{2}{*}{ Treatment } & \multirow{2}{*}{$\begin{array}{l}\text { Experiment } \\
\text { No. }\end{array}$} & \multirow{2}{*}{$\begin{array}{c}\text { Moisture } \\
\text { of } \\
\text { leaves, } \\
\text { per cent }\end{array}$} & \multirow{2}{*}{$\begin{array}{c}\mathrm{HCN} \\
\text { added, mg }\end{array}$} & \multicolumn{2}{|c|}{ HCN recovered } \\
\hline & & & & Amount, mg & Per cent \\
\hline \multirow{5}{*}{$\mathrm{HCN}$ added to leaf distillate. } & 255 & 58.5 & 41.7 & 40.9 & 98.1 \\
\hline & 256 & 57.5 & 35.1 & 34.7 & 98.9 \\
\hline & 257 & 57.5 & 53.6 & 53.1 & 99.1 \\
\hline & 258 & 57.5 & 25.7 & 25.7 & 100.0 \\
\hline & Average & $\ldots$ & $\cdots$ & $\ldots$ & 99.0 \\
\hline \multirow{6}{*}{$\begin{array}{r}\mathrm{HCN} \text { distilled in presence of } \\
\text { leaves..................... }\end{array}$} & 259 & 57.6 & 45.0 & 43.8 & 97.3 \\
\hline & 260 & 57.6 & 34.8 & 33.0 & 94.8 \\
\hline & 261 & 59.5 & 41.2 & 39.0 & 94.7 \\
\hline & 262 & 59.5 & 19.5 & 18.8 & 96.4 \\
\hline & 263 & 57.0 & 25.8 & 24.7 & 95.7 \\
\hline & Average & $\ldots$ & $\ldots$ & $\ldots$ & 95.8 \\
\hline
\end{tabular}

Tests (see table 2) had shown that the HCN had not escaped from the flask; therefore it appeared that either the tissues were not finely enough divided to permit all of the HCN to escape during the process of distillation, or a certain amount of the HCN was chemically bound or changed within the tissues during the periods of fumigation and distillation. An attempt to solve this problem was made by grinding 200-gram lots of fresh leaves to pass a 2-mm screen in a Wiley mill and by exposing the lots of ground tissues to known quantities of HCN in the distillation flask

\section{TABLE 7}

Amounts of HCN Recovered From Ground and Fumigated Citrus Leaf Tissue and From Citrus Leaves That Had Been Washed to Remove HCN Adhering to Their Surfaces

\begin{tabular}{|c|c|c|c|c|c|}
\hline \multirow{2}{*}{ Material used } & \multirow{2}{*}{$\begin{array}{l}\text { Experiment } \\
\text { No. }\end{array}$} & \multirow{2}{*}{$\begin{array}{c}\text { Moisture } \\
\text { in } \\
\text { leaves, } \\
\text { per cent }\end{array}$} & \multirow{2}{*}{$\begin{array}{c}\mathrm{HCN} \\
\text { added, mg }\end{array}$} & \multicolumn{2}{|c|}{$\mathrm{HCN}$ recovered } \\
\hline & & & & Amount, mg & Per cent \\
\hline \multirow{5}{*}{ Washed leaves. } & 232 & 59.5 & 38.7 & 26.4 & 68.2 \\
\hline & 233 & 59.5 & 43.0 & 26.4 & 61.4 \\
\hline & 235 & 59.5 & 28.8 & 20.6 & 71.5 \\
\hline & 236 & 59.4 & 46.8 & 29.9 & 63.9 \\
\hline & Average & $\ldots$ & $\ldots$ & $\ldots$ & 66.3 \\
\hline \multirow{6}{*}{ Ground leaf tissue. } & 211 & 59.7 & 0.0 & 0.0 & 0.0 \\
\hline & 207 & 60.0 & 42.6 & 33.7 & 79.1 \\
\hline & 208 & 61.5 & 23.8 & 19.1 & 80.3 \\
\hline & 209 & 57.6 & 47.5 & 36.8 & 77.5 \\
\hline & 210 & 60.5 & 27.8 & 23.1 & 83.1 \\
\hline & Average & $\ldots$ & $\ldots$ & $\ldots$ & 80.0 \\
\hline
\end{tabular}


for a period of 45 minutes before distillation was begun. In these tests, the average recovery of HCN was only 80.0 per cent, as shown in the second group of data in table 7 .

Several series of experiments were carried out to determine the effects of different experimental treatments on the amounts of $\mathrm{HCN}$ that could be recovered from leaves. The treatments used are shown in table 8 . The double-distillation process was used in all of the tests, and either gas or

TABLE 8

Amounts of HCN Recovered from 200-Gram Lots of Citrus Leaves Fumigated and Distilled under DiFferent EXPERIMENTAL Conditions

\begin{tabular}{|c|c|c|c|c|c|c|c|}
\hline \multirow{2}{*}{ Treatment* } & \multirow{2}{*}{$\begin{array}{l}\text { Experiment } \\
\text { No. }\end{array}$} & \multirow{2}{*}{$\begin{array}{c}\text { Moisture } \\
\text { in } \\
\text { leaves, } \\
\text { per cent }\end{array}$} & \multirow{2}{*}{$\begin{array}{c}\mathrm{HCN} \\
\text { added, } \\
\text { mg }\end{array}$} & \multicolumn{2}{|c|}{$\mathrm{HCN}$ recovered } & \multicolumn{2}{|c|}{$\begin{array}{l}\text { HCN not recovered } \\
\text { by distillation }\end{array}$} \\
\hline & & & & $\underset{\mathrm{mg}}{\operatorname{Amount}}$ & Per cent & $\underset{\mathrm{mg}}{\text { Amount, }}$ & Per cent \\
\hline \multicolumn{8}{|c|}{ Series A, 100 grams of leaves, fumigated 45 minutes } \\
\hline $\begin{array}{l}\text { Solutions acidified with } \\
\qquad \mathrm{H}_{2} \mathrm{SO}_{4} \ldots \ldots \ldots \ldots \ldots \ldots\end{array}$ & $\begin{array}{l}180 \\
181 \\
182 \\
183 \\
\text { Average }\end{array}$ & $\begin{array}{l}54.3 \\
52.5 \\
53.5 \\
52.2 \\
\ldots .\end{array}$ & \begin{tabular}{l|}
51.8 \\
31.7 \\
29.6 \\
32.9 \\
$\ldots$.
\end{tabular} & $\begin{array}{c}47.1 \\
28.2 \\
26.5 \\
29.6 \\
\ldots .\end{array}$ & $\begin{array}{l}90.9 \\
89.0 \\
89.5 \\
90.0 \\
89.9\end{array}$ & $\begin{array}{c}4.7 \\
3.5 \\
3.1 \\
3.3 \\
\ldots \ldots\end{array}$ & $\begin{array}{r}9.1 \\
11.0 \\
10.5 \\
10.0 \\
10.1\end{array}$ \\
\hline $\begin{array}{l}\text { Solutions acidified with } \\
\quad \text { tartaric acid .......... }\end{array}$ & $\begin{array}{l}184 \\
185 \\
186 \\
187 \\
188 \\
\text { Average }\end{array}$ & $\begin{array}{l}55.3 \\
55.5 \\
54.8 \\
56.0 \\
53.8 \\
\ldots .\end{array}$ & \begin{tabular}{l|}
39.8 \\
41.9 \\
47.9 \\
48.3 \\
13.4 \\
$\ldots$.
\end{tabular} & $\begin{array}{l}35.1 \\
37.2 \\
41.0 \\
43.4 \\
10.9 \\
\ldots .\end{array}$ & $\begin{array}{l}88.2 \\
88.8 \\
85.6 \\
89.9 \\
81.3 \\
86.8\end{array}$ & $\begin{array}{c}4.7 \\
4.7 \\
6.9 \\
4.9 \\
2.5 \\
\ldots .\end{array}$ & \begin{tabular}{l|}
11.8 \\
11.2 \\
14.4 \\
10.1 \\
18.7 \\
13.2
\end{tabular} \\
\hline \multicolumn{8}{|c|}{ Series $B, 200$ grams of leaves, fumigated 90 minutes } \\
\hline $\begin{array}{l}\text { Solutions acidified with } \\
\qquad \mathrm{H}_{2} \mathrm{SO}_{4} \ldots \ldots \ldots \ldots \ldots \ldots\end{array}$ & $\begin{array}{l}195 \\
196 \\
197 \\
198 \\
\text { Average }\end{array}$ & $\begin{array}{l}57.8 \\
58.0 \\
59.0 \\
60.0 \\
\ldots \ldots\end{array}$ & $\begin{array}{l}32.8 \\
34.8 \\
47.5 \\
38.4 \\
\ldots \ldots\end{array}$ & \begin{tabular}{l|}
26.5 \\
29.2 \\
39.9 \\
32.6 \\
$\ldots \ldots$
\end{tabular} & $\begin{array}{l}80.8 \\
83.9 \\
84.0 \\
84.9 \\
83.4\end{array}$ & $\begin{array}{c}6.3 \\
5.6 \\
7.6 \\
5.8 \\
\ldots \ldots\end{array}$ & $\begin{array}{l}19.2 \\
16.1 \\
16.0 \\
15.1 \\
16.6\end{array}$ \\
\hline $\begin{array}{l}\text { Solutions acidified with } \\
\quad \text { tartaric acid } \ldots \ldots \ldots \ldots \ldots\end{array}$ & $\begin{array}{l}189 \\
190 \\
191 \\
192 \\
193 \\
\text { Average }\end{array}$ & $\begin{array}{l}\mathbf{5 6 . 2} \\
\mathbf{5 6 . 7} \\
55.7 \\
55.0 \\
53.9 \\
\ldots .\end{array}$ & \begin{tabular}{l|}
28.7 \\
31.9 \\
42.7 \\
48.9 \\
25.5 \\
$\ldots$.
\end{tabular} & $\begin{array}{l}20.4 \\
25.1 \\
33.5 \\
39.1 \\
17.7 \\
\ldots .\end{array}$ & $\begin{array}{l}71.1 \\
78.7 \\
78.5 \\
80.0 \\
69.4 \\
75.5\end{array}$ & \begin{tabular}{r|}
8.3 \\
6.8 \\
9.2 \\
9.8 \\
7.8 \\
$\ldots$.
\end{tabular} & $\begin{array}{l}28.9 \\
21.3 \\
21.5 \\
20.0 \\
30.6 \\
24.5\end{array}$ \\
\hline $\begin{array}{l}\text { No acid in first distillation, } \\
\mathrm{H}_{2} \mathrm{SO}_{4} \text { used in second.... }\end{array}$ & $\begin{array}{l}202 \\
203 \\
204 \\
205 \\
\text { Average }\end{array}$ & $\begin{array}{l}61.5 \\
60.7 \\
55.1 \\
58.3 \\
\ldots \ldots\end{array}$ & \begin{tabular}{l|l|}
23.3 & \\
41.4 & \\
37.8 & \\
23.5 & \\
$\ldots$. &
\end{tabular} & \begin{tabular}{l|l|}
18.8 \\
36.0 \\
33.3 \\
19.1 \\
$\ldots .$.
\end{tabular} & $\begin{array}{l}80.7 \\
87.0 \\
88.1 \\
81.3 \\
84.3\end{array}$ & \begin{tabular}{r|}
4.5 \\
5.4 \\
4.5 \\
4.4 \\
$\ldots$.
\end{tabular} & $\begin{array}{l}19.3 \\
13.0 \\
11.9 \\
18.7 \\
15.7\end{array}$ \\
\hline
\end{tabular}

* All distillations were made by using direct gas or electric heat, except as indicated for the second group of tests in series $C$. 
TABLE 8 (Continued)

\begin{tabular}{l|l|l|l|l|l|l}
\hline \hline Treatment* & $\begin{array}{c}\text { Experiment } \\
\text { No. }\end{array}$ & $\begin{array}{c}\text { Moisture } \\
\text { in } \\
\text { leaves, } \\
\text { per cent }\end{array}$ & $\begin{array}{c}\text { added, } \\
\text { mg }\end{array}$ & $\begin{array}{c}\text { Amount, } \\
\text { mg }\end{array}$ & Per cent & $\begin{array}{c}\text { Amon not recovered } \\
\text { by distillation } \\
\text { mg }\end{array}$ \\
\cline { 1 - 1 }
\end{tabular}

Series C, 200 grams of leaves, fumigated 45 minutes

\begin{tabular}{|c|c|c|c|c|c|c|c|}
\hline \multirow{5}{*}{$\begin{array}{l}\text { No acid in first distillation, } \\
\mathrm{H}_{2} \mathrm{SO}_{4} \text { used in second.... }\end{array}$} & 194 & 54.8 & 40.7 & 33.2 & 81.6 & 7.5 & 18.4 \\
\hline & 199 & 59.7 & 33.1 & 29.0 & 87.6 & 4.1 & 12.4 \\
\hline & 200 & 56.3 & 53.0 & 45.7 & 86.2 & 7.3 & 13.8 \\
\hline & 201 & 60.5 & 46.0 & 40.1 & 87.2 & 5.9 & 12.8 \\
\hline & Average & $\ldots$ & $\ldots$ & $\ldots$ & 85.6 & $\ldots$ & 14.4 \\
\hline \multirow{5}{*}{$\begin{array}{l}\text { Steam distillation, solu- } \\
\text { tions acidified with } \\
\mathrm{H}_{2} \mathrm{SO}_{4} \ldots \ldots \ldots \ldots \ldots \ldots \ldots\end{array}$} & 224 & 59.5 & 56.8 & 50.1 & 88.2 & 6.7 & 11.8 \\
\hline & 226 & 61.7 & 45.8 & 38.5 & 84.1 & 7.3 & 15.9 \\
\hline & 228 & 58.6 & 49.4 & 42.2 & 85.4 & 7.2 & 14.6 \\
\hline & 229 & 57.3 & 34.9 & 28.9 & 82.8 & 6.0 & 17.2 \\
\hline & Average & $\ldots$ & $\ldots$ & $\ldots$ & 85.1 & $\ldots$ & 14.9 \\
\hline \multirow{5}{*}{$\begin{array}{l}\text { Solutions acidified with } \\
\qquad \mathrm{H}_{2} \mathrm{SO}_{4} \ldots \ldots \ldots \ldots \ldots \ldots\end{array}$} & 220 & 59.8 & 37.3 & 32.5 & 87.1 & 4.8 & 12.9 \\
\hline & 221 & 57.7 & 54.7 & 47.4 & 86.7 & 7.3 & 13.3 \\
\hline & 273 & 62.0 & 51.3 & 45.5 & 88.7 & 5.8 & 11.3 \\
\hline & 274 & 62.0 & 45.0 & 38.9 & 86.4 & 6.1 & 13.6 \\
\hline & Average & $\ldots$ & $\ldots$ & $\ldots$ & 87.2 & $\ldots$ & 12.8 \\
\hline
\end{tabular}

Series D, 200 grams of young leaves, fumigated 45 minutes

\begin{tabular}{|c|c|c|c|c|c|c|c|}
\hline \multirow{7}{*}{$\begin{array}{l}\text { Solutions acidified with } \\
\mathrm{H}_{2} \mathrm{SO}_{4} \ldots \ldots \ldots \ldots \ldots \ldots\end{array}$} & 212 & 76.4 & 38.7 & 31.7 & 81.9 & 7.0 & 18.1 \\
\hline & 213 & 75.5 & 37.6 & 26.7 & 71.0 & 10.9 & 29.0 \\
\hline & 214 & 75.9 & 38.6 & 26.1 & 67.6 & 12.5 & 32.4 \\
\hline & 216 & 73.4 & 47.6 & 31.9 & 67.0 & 15.7 & 33.0 \\
\hline & 217 & 75.9 & 39.6 & 32.4 & 81.8 & 7.2 & 18.2 \\
\hline & 215 & 74.3 & 0.0 & 0.0 & 0.0 & 0.0 & 0.0 \\
\hline & Average & $\ldots$ & $\ldots$ & $\ldots$ & 73.9 & $\ldots$ & 26.1 \\
\hline
\end{tabular}

* All distillations were made by using direct gas or electric heat, except as indicated for the second group of tests in series $\mathbf{C}$.

electric heat was applied directly to the distillation flask, except as indicated for the second group in series C. All leaves were mature except those in series $\mathrm{D}$, which were about two-thirds mature. The temperature during the fumigation periods was always between $21^{\circ}$ and $25^{\circ} \mathrm{C}$, and in most cases it was $22^{\circ}$ to $23^{\circ}$. The leaves were not removed from the flask before making the distillation, as had been done in the tests recorded in table 5 . The distillation solution was run into the flask through the separatory funnel and none of the $\mathrm{HCN}$ was allowed to escape. The recoveries therefore represent not only the recoverable portion of the HCN that had been absorbed by the leaves but also that which remained unabsorbed in the flask at the end of the fumigation period.

Series A of table 8 shows that the average percentage of $\mathrm{HCN}$ recov- 
ered from 100-gram lots of leaves fumigated for 45 minutes and distilled from water acidulated with $\mathrm{H}_{2} \mathrm{SO}_{4}$ was 89.9 per cent, and those acidulated with tartaric acid gave a recovery of 86.8 per cent.

In table 8, series B, 200-gram instead of 100-gram lots of leaves were used. The treatments were similar except that the fumigation periods were 90 instead of 45 minutes and that in the last four tests in this series the leaves were distilled in nonacidulated water. The average recoveries for the three groups in this series were : acidulated with $\mathrm{H}_{2} \mathrm{SO}_{4}, 83.4$ per cent; acidulated with tartaric acid, 75.5 per cent; and nonacidulated, 84.3 per cent.

In series $\mathrm{C}$ of table 8 , the treatment of the first group was the same as that of the last group in series B, except that the fumigation periods were 45 minutes instead of 90 . The average percentage of $\mathrm{HCN}$ recovered was 85.6. The second and third groups of data in series $\mathrm{C}$ show the comparative effects of steam distillation and distillation with direct heat. The average percentages of recovery of HCN were 85.1 and 87.2, respectively. Although no statistical studies have been made, the variations within the groups indicate that the differences are not significant.

A comparison of the amounts of $\mathrm{HCN}$ recovered from mature leaves and from those having reached only about two-thirds full size can be made from the results recorded in the last group of series $\mathrm{C}$ (mature) in table 8 , and in series $\mathrm{D}$ (young). The average percentages of $\mathrm{HCN}$ recovered were 87.2 and 73.9 , respectively.

\section{THE RECOVERY OF HCN FROM CITRUS-FRUIT DISTILLATES}

The green and mature citrus fruits tested were all picked from the same block of trees, a standard orange clipper being used to cut the stem. After picking they were immediately brought to the laboratory, counted into lots-usually of 15 each-weighed, and the diameters measured.

In working with the young, green orange fruits, the same precautions as had been used with the leaves were necessary. In the first tests, the green fruits were cut into small pieces and treated like the leaves. A known quantity of $\mathrm{HCN}$ was dissolved in a solution of $\mathrm{NaOH}$ of the usual strength, placed in the flask with the sliced fruits, and distilled at once.

In addition to $\mathrm{H}_{2} \mathrm{~S}$, which had caused trouble in making determinations from the leaf extracts and which was taken care of by using $\mathrm{CdSO}_{4}$, there appeared to be a substance or substances in the distillate which slowly reacted with the HCN. In order to check on this possibility, the amounts of HCN in the distillates were determined immediately after distillation and then again after the distillate had stood for 24 hours. 
The results of these tests are shown in table 9. The quantities of $\mathrm{HCN}$ added before distillation plotted against the quantities recovered in the distillate immediately after distillation show a straight-line relation (graph not included in this paper).

TABLE 9

Amounts of HCN Recovered From the Distillate From Green and Mature VALENCIA Fruits

(The HCN was added either immediately before or after distillation; there was no fumigation period)

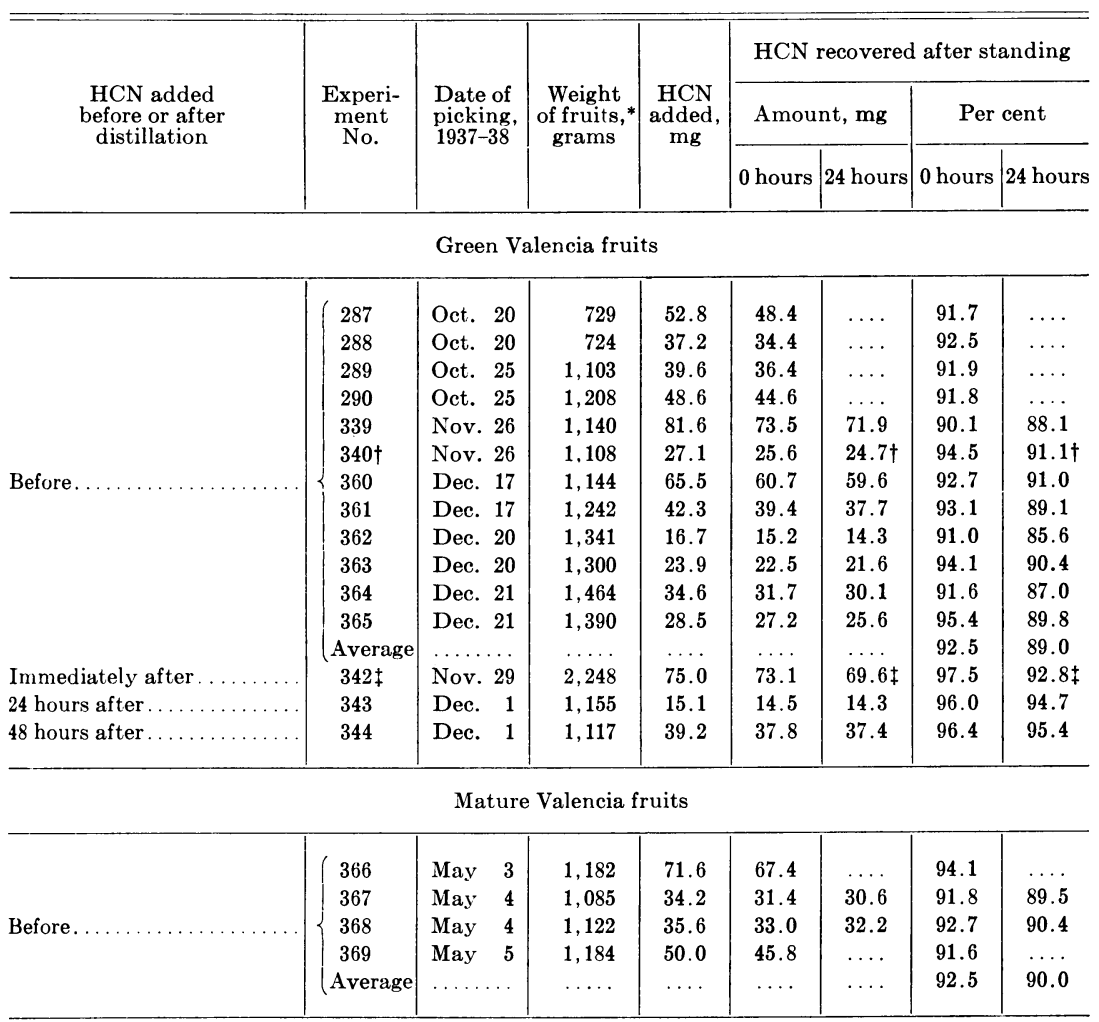

* The number of fruits was 15 except as follows: experiment No. 287, 13 fruits; No. 288, 13; No. 342, 30; No. 366,7 ; No. 367,7 ; No. 368,8 ; and No. 369,8 .

$\dagger$ After 72 hours, $23.7 \mathrm{mg}, 87.5$ per cent.

$\ddagger$ After 48 and 72 hours, 69.0 and $68.5 \mathrm{mg}, 92.0$ and 91.3 per cent, respectively.

Further trials were made, not only by adding a known quantity of HCN immediately before distillation and by making determinations on the distillate at intervals, but also by adding known quantities of HCN to distillates from unfumigated fruits and by making determinations at once and at 24 - and 48-hour intervals. The results of these tests are also 
given in table 9 . The leaf extracts appeared to contain similar substances, but no definite tests were made to determine the amounts of HCN that combined with them after given intervals of time.

Several months later similar tests were made on mature Valencia fruits taken from the same trees. The color of the distillate indicated that the amount of $\mathrm{H}_{2} \mathrm{~S}$ in the mature fruits was less than that in the green fruits; however, enough was present so that it was necessary to use $\mathrm{CdSO}_{4}$ in the distillation flask. The amounts of $\mathrm{HCN}$ recovered from the different lots of mature fruits are given in the lower section of table 9 .

In the next series of tests, different lots of green fruits were fumigated for 40 minutes in a 100-cu. ft. gastight metal fumatorium with different amounts of HCN.

The amounts of HCN used for fumigation at different times ranged from $0.88 \mathrm{mg}$ to $3.66 \mathrm{mg}$ per liter of space in the fumatorium. The fumigation temperature was always maintained at $24^{\circ} \mathrm{C}$. The period of fruit aeration after fumigation ranged from 5 minutes to 44 hours; the two periods most used were 10 minutes and 22 hours. A fan kept the gases in the fumatorium in constant circulation during the entire fumigation period. The concentration of $\mathrm{HCN}$ in the fumatorium was measured four times during a fumigation period.

After fumigation, each fumigated fruit was cut into 10 to 15 pieces and placed in the distillation flask with 3 liters of acidulated distilled water and 30 grams of $\mathrm{CdSO}_{4}$. It was necessary to make only a single distillation with the fruits because the tissues were more nearly completely immersed in the distillation liquid. In experiments 281 to 334, inclusive, the fruits were distilled by direct heating. In experiments 337 to 369 , inclusive (Nos. 342 to 369 not included in table 10), they were steam-distilled. One liter of distillate was caught in $\mathrm{NaOH}$ as described for the leaves. After filtering the distillate, 150-ml aliquots were used for titration.

Table 10 shows the amounts of HCN recovered from green Valencia oranges that had been fumigated in the fumatorium. Four to eight lots of fruit were used in each experiment. The amount of $\mathrm{HCN}$ recovered was roughly in direct proportion to the concentration of $\mathrm{HCN}$ in the fumatorium, as shown in figure 1. The figure does not show it, but the amount of HCN recovered from the fruit was inversely proportional to the length of the aeration period. No HCN could be detected after 44 hours' aeration.

The data recorded in table 11 are similar to those in table 10, except that, although in all cases the whole fruits were fumigated, the peels and pulps of some lots were distilled separately. This was done in order to 
TABLE 10

Amounts of HCN Recovered From the Distillate rrom Green Valencia Oranges Fumigated With Different Amounts of HCN in the Fumatorium

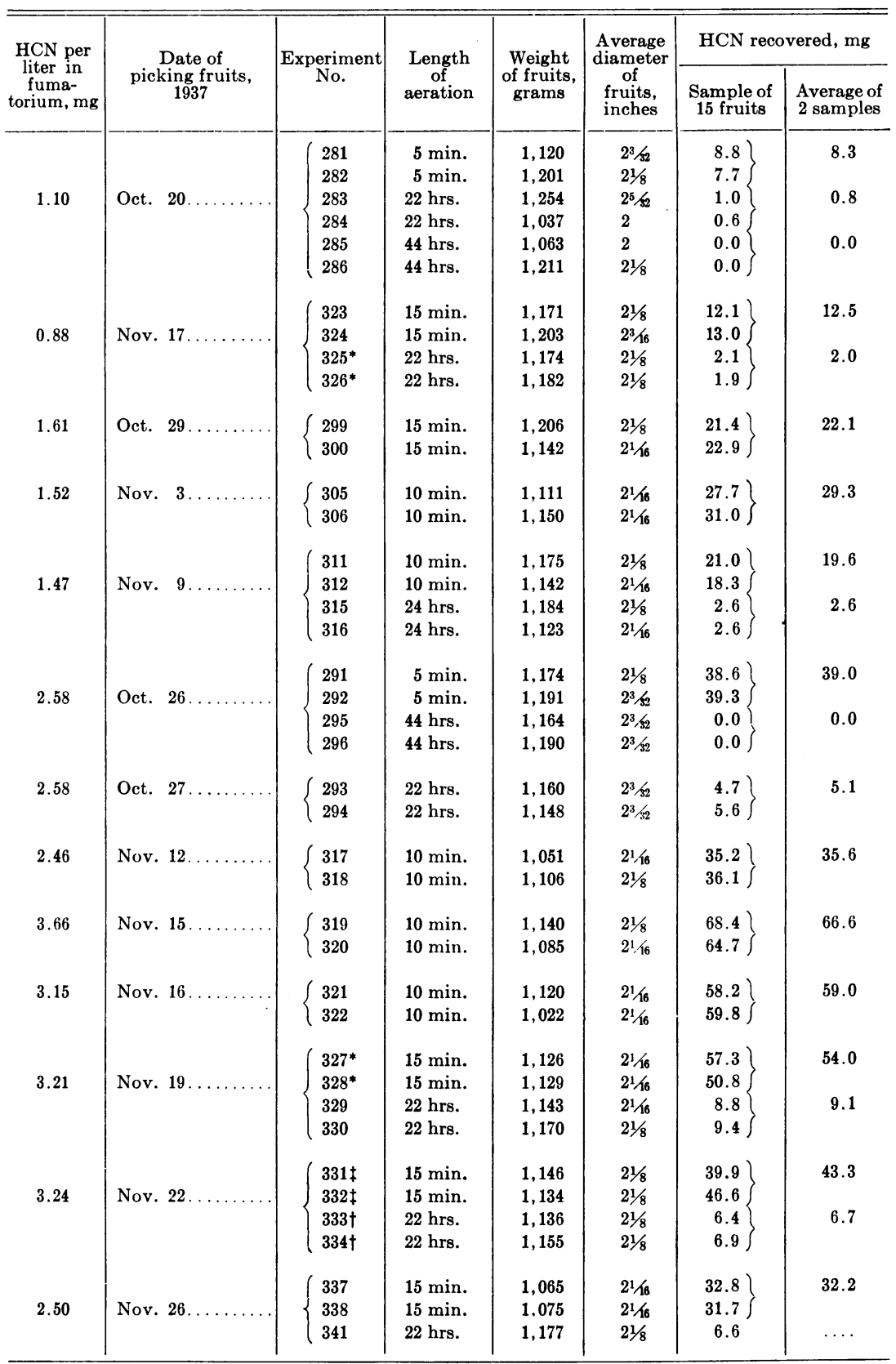

*, ‡, † Tested 24, 42, and 72 hours, respectively, after distillation. No earlier titrations were made. 
determine the depth of penetration of the HCN into the fruits during the fumigation period and during the interval between fumigation and distillation. In order to guard as much as possible against the loss of $\mathrm{HCN}$, the fruits were dipped in distilled water before peeling and the water was added to the distillation solution. In this connection it may be

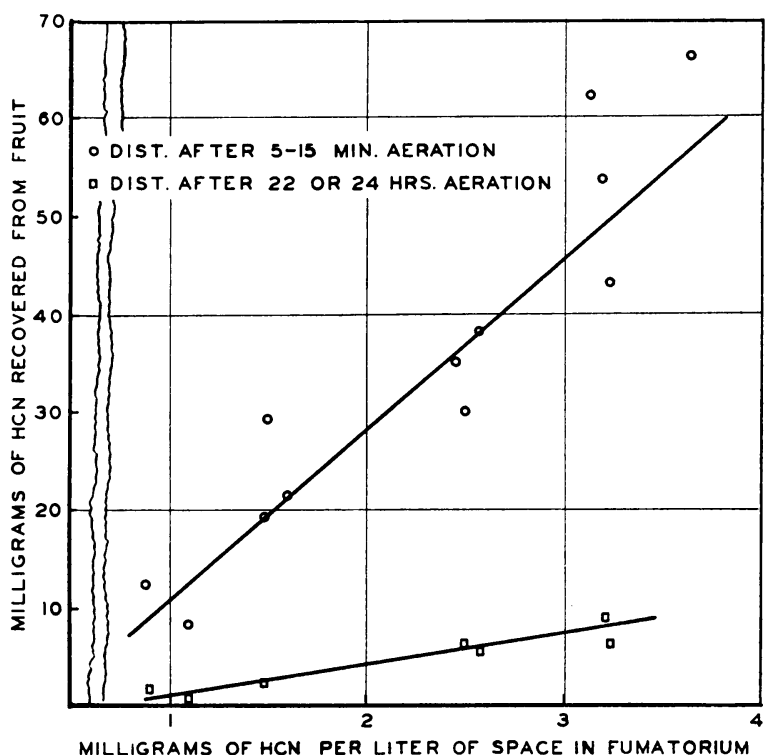

Fig. 1.- The amounts of HCN that were placed in the 100-cu.-ft. fumatorium with different lots of green Valencia fruits, and the amounts of $\mathrm{HCN}$ recovered from them by subsequent distillations (see table 10).

mentioned that citrus fruits are acid and such a condition favors the release of $\mathrm{HCN}$. The determinations were made on all of the distillates immediately, and then again 24 or 48 hours later.

\section{DISCUSSION}

A nonvolatile organic acid of low concentration is usually recommended and used in the recovery of HCN from biological materials by the distillation method. Krieble and Peiker (5) found that hydrolysis of the HCN will occur, and Cobb and Walton (4) have shown that HCN forms complexes with $\mathrm{H}_{2} \mathrm{SO}_{4}$, if the acid concentrations are too high. However, Pagel and Carlson (7) and Morris and Lilly (6) reported satisfactory recovery when $\mathrm{HCN}$ was distilled from solutions acidified with $\mathrm{H}_{2} \mathrm{SO}_{4}$.

Most of the distillations reported in these experiments were made in the presence of $\mathrm{H}_{2} \mathrm{SO}_{4}$. This acid was used because, as shown in series $\mathrm{A}$ 
and the first two groups of series B in table 8 (p. 482), a greater percentage of the $\mathrm{HCN}$ could be recovered by using $\mathrm{H}_{2} \mathrm{SO}_{4}$ than by using tartaric acid. Furthermore, for some unknown reason, titration to the end point was somewhat more difficult when tartaric acid was used. As has been stated already, in the earlier tests, $0.30 \mathrm{ml}$, but in the later tests only $0.15 \mathrm{ml}$, of concentrated $\mathrm{H}_{2} \mathrm{SO}_{4}$, beyond neutrality, was used in the 3 liters of solution in the distillation flask. It should be borne in mind

\section{TABLE 11}

Amounts of HCN Recovered from Fumigated Green Valencia Oranges and From Their Peels and Pulps Separately

(The determinations were made immediately after distillation and 24 or 48 hours later)

\begin{tabular}{|c|c|c|c|c|c|c|c|c|c|c|c|}
\hline \multirow{2}{*}{$\begin{array}{l}\mathrm{HCN} \\
\text { per } \\
\text { liter in } \\
\text { fuma- } \\
\text { torium, } \\
\text { mg }\end{array}$} & \multirow{2}{*}{$\begin{array}{c}\text { Date } \\
\text { of } \\
\text { picking, } \\
1937\end{array}$} & \multirow{2}{*}{$\begin{array}{l}\text { Length of } \\
\text { aeration }\end{array}$} & \multirow{2}{*}{$\begin{array}{c}\text { Average } \\
\text { dia- } \\
\text { meter } \\
\text { of } \\
\text { fruits, } \\
\text { inches }\end{array}$} & \multirow{2}{*}{$\begin{array}{l}\text { Weight } \\
\text { of } \\
\text { fruits, } \\
\text { grams }\end{array}$} & \multirow{2}{*}{$\begin{array}{c}\text { Experi- } \\
\text { ment } \\
\text { No. }\end{array}$} & \multirow{2}{*}{$\begin{array}{c}\text { Part } \\
\text { of } \\
\text { fruit } \\
\text { distilled }\end{array}$} & \multicolumn{3}{|c|}{$\begin{array}{l}\mathrm{HCN} \text { recovered } \\
\text { after standing, } \mathrm{mg}\end{array}$} & \multicolumn{2}{|c|}{$\begin{array}{l}\text { HCN lost on } \\
\text { standing, mg }\end{array}$} \\
\hline & & & & & & & $\begin{array}{c}0 \\
\text { hrs. }\end{array}$ & $\begin{array}{l}24 \\
\text { hrs. }\end{array}$ & $\begin{array}{c}48 \\
\text { hrs. }\end{array}$ & $\begin{array}{c}24 \\
\text { hrs. }\end{array}$ & $\begin{array}{l}48 \\
\text { hrs. }\end{array}$ \\
\hline \multirow{3}{*}{2.50} & \multirow{3}{*}{ Nov. 26} & $(15 \mathrm{~min}$. & $2^{1 / 16}$ & 1,065 & 337 & Whole & 32.8 & 31.7 & $\ldots$ & 1.1 & \\
\hline & & $15 \mathrm{~min}$. & $21 / 16$ & 1,075 & 338 & Whole & 31.7 & 29.7 & $\ldots$ & 2.0 & $\ldots$. \\
\hline & & $22 \mathrm{hrs}$ & $21 / 8$ & 1,177 & 341 & Whole & 6.6 & $\ldots$ & 5.0 & $\ldots$ & 1.6 \\
\hline \multirow{2}{*}{1.68} & \multirow{2}{*}{ Nov. 24} & \multirow{2}{*}{$15 \mathrm{~min}}$. & \multirow{2}{*}{$21 / 16$} & \multirow{2}{*}{1,087} & 335 & Peel & 19.8 & .. & 17.7 & & 2.1 \\
\hline & & & & & 336 & Pulp & 2.6 & $\ldots$. & 2.0 & $\ldots$ & 0.6 \\
\hline \multirow{6}{*}{1.59} & \multirow{6}{*}{ Dec. 2} & \multirow{2}{*}{$15 \mathrm{~min}}$. & \multirow{2}{*}{$21 / 16$} & \multirow{2}{*}{1,149} & 345 & Peel & 15.8 & 14.4 & & 1.4 & $\ldots$ \\
\hline & & & & & 346 & Pulp & 3.2 & 2.3 & $\ldots$ & 0.9 & $\ldots$ \\
\hline & & \multirow{2}{*}{$4 \mathrm{hrs}$. } & \multirow{2}{*}{$21 / 8$} & \multirow{2}{*}{1,213} & 347 & Peel & 5.5 & 5.0 & & 0.5 & $\ldots$ \\
\hline & & & & & 348 & Pulp & 1.9 & 1.2 & $\ldots$ & 0.7 & $\ldots$ \\
\hline & & \multirow{2}{*}{$22 \mathrm{hrs}$. } & \multirow{2}{*}{$21 / 16$} & \multirow{2}{*}{1,133} & 349 & Peel & 2.0 & 1.9 & $\ldots$ & 0.1 & $\ldots$ \\
\hline & & & & & 350 & Pulp & 0.6 & 0.4 & $\ldots$ & 0.2 & $\ldots$ \\
\hline
\end{tabular}

that neither of these concentrations of $\mathrm{H}_{2} \mathrm{SO}_{4}(0.0176$ per cent, $0.0036 \mathrm{~N}$, and 0.0088 per cent, $0.0018 \mathrm{~N}$, respectively) furnished the solutions with as many free $\mathrm{H}$-ions as were available in the 2 per cent $(0.2666 \mathrm{~N})$ tartaric acid solution. Table 4 ( $\mathrm{p} 479$ ) shows that the same average recovery of $\mathrm{HCN}$ was obtained with $\mathrm{H}_{2} \mathrm{SO}_{4}$ as with tartaric acid when the distillations were made in the absence of leaves.

Distillations were made with steam or, more often, with heat from a free flame or an electric heater. The results given in treatment $\mathrm{C}$ of table 2 (p. 475) show that the application of direct heat did not cause a measurable destruction of $\mathrm{HCN}$, probably because of the high vapor pressure of $\mathrm{HCN}$, which caused it to distill rapidly, and because of its very low concentration in the solution in the distillation flask.

The liquid HCN used in the experiments reported in this paper was 
guaranteed to contain 96 per cent available HCN. Corrections have accordingly been made to a basis of 100 per cent available $\mathrm{HCN}$ wherever percentages of recovery are given. However, when the distillations were made in the absence of tissues, the recoveries (see table 2, treatment $B$, and table 4) indicate that the amount of available HCN was approximately 96.5 per cent.

All of the HCN could not be recovered from citrus leaf tissues. Repeated tests showed that no additional $\mathrm{HCN}$ could be recovered from the fumigated tissues by driving over more than 800 to $900 \mathrm{ml}$ of distillate or by redistilling the tissues. Tests also showed that none of the HCN was escaping from the receiving vessel. This was determined by using a chain of receiving vessels. All of the $\mathrm{HCN}$ was caught in the first unit.

The leaves appear to contain a substance or substances which combine with a portion of the $\mathrm{HCN}$ in such a manner that it either is no longer volatile, or if it does distill over, will not react with standard $\mathrm{AgNO}_{3}$. More $\mathrm{HCN}$ could be recovered when the distillations were made as soon as the $\mathrm{HCN}$ had been added than when the tissues were exposed to it during a 45-minute fumigation period. This is shown very well by the data in tables 6 and 8 . Table 6 (p. 481) shows that 99.0 per cent of the HCN could be recovered when it was distilled at once from leaf distillate and 95.8 per cent when distilled at once in the presence of unfumigated leaves. These percentages of recovery are considerably higher than those obtained by making the distillations after a 45-minute fumigation period. Under such conditions the highest percentages of recovery from 100 gram and 200-gram samples of mature leaves were 89.9 per cent and 87.2 per cent, respectively, while the recovery from 200-gram samples of immature leaves was only 73.9 per cent (see table 8 , p. 482). Such results indicate that at least a certain amount of $\mathrm{HCN}$ can be chemically bound or fixed by citrus leaf tissues. Apparently biological or other factors prevented proportionality fixation.

Because of the manner in which the fruits were fumigated, the percentages of HCN recovered from them cannot be computed. That the fruits, as well as the leaves, fixed a certain amount of the HCN during the fumigation period is indicated by the fact that when unfumigated fruits were placed in an alkaline $\mathrm{HCN}$ solution and distilled at once, only about 92 per cent of the $\mathrm{HCN}$ could be recovered (table 9, p. 485). This is more strikingly shown in results that have not been described or tabulated. When different lots of fruits were exposed to $1.61 \mathrm{mg}$ of $\mathrm{HCN}$ per liter of space in the fumatorium and distilled, after a 15-minute period of aeration, about $22 \mathrm{mg}$ of $\mathrm{HCN}$ was recovered. However, when other lots of fruit, which had been fumigated at the same time, were placed in 
desiccators over $\mathrm{NaOH}$ and left for 17 and 64 hours, averages of only $8.9 \mathrm{mg}$ and $2.3 \mathrm{mg}$, respectively, could be recovered from the fruits and their underlying $\mathrm{NaOH}$.

In studying the cyanophoric glucosides in such plants as Prunus virginiana and Andropogon Sorghum, Alsberg and Black (1) found that not only all autogenous HCN in the tissues could be obtained but also that 100 per cent of any added $\mathrm{HCN}$ could be recovered if the distillation were made at once. These results do not agree with those reported in this paper for citrus tissues. Immediate distillation did not recover all of the added $\mathrm{HCN}$, and the more finely divided the tissues were before being fumigated or the younger the tissue, the less the percentage that could be recovered. Only about 80 per cent could be recovered when the mature leaf tissues were finely ground, fumigated, and distilled at once (table 7 , p. 481), and only about 74 per cent from whole, immature leaves (table 8 , p. 482). From these and other studies (10) it appears that the amount of $\mathrm{HCN}$ fixed or chemically changed during and after fumigation depends upon the kind of plant tissue that is being tested.

In this connection it may be repeated that Bartholomew and Raby (3) found that citrus leaf and fruit tissues do not contain a cyanophoric glucoside. These results have been verified in the present investigation (for example, see experiment 211, table 7, p. 481).

Although studies in this field have been outlined, no attempt was made during the course of these experiments to determine the nature or identity of the substances which prevented the recovery of all of the HCN. Bartholomew and Raby (3) found that full recoveries could be made when HCN was distilled in the presence of sugars, citral, or pure citrus oils. They found, however, that small amounts of aldehydes can be recovered from green citrus tissues and that these may be at least partially responsible for the fixation of the $\mathrm{HCN}$ that could not be recovered after distillation in the presence of the tissues. Whether these substances or others were responsible for the progressive disappearance of titratable $\mathrm{HCN}$ from the distillate from citrus tissues upon standing is not known. Maximum determinations of $\mathrm{HCN}$ in the distillates were obtained by titrating immediately after distillation.

That the disappearance of $\mathrm{HCN}$, in such dilute solutions as were used, could not have been caused except by its being combined with substances in or distilled from the tissues was determined by experimentation. Thirty-one $\mathrm{mg}$ of $\mathrm{NaCN}$ were dissolved in 1 liter of distilled $\mathrm{H}_{2} \mathrm{O}$, and 125 liters of air per hour were bubbled through it over a period of 24 hours. At the end of the period the solution contained the same amount of $\mathrm{NaCN}$ as at the beginning. 
That the HCN had actually penetrated the leaves during the period of fumigation and was not merely adhering to their surfaces was shown by the fact that an average of 66.3 per cent of the $\mathrm{HCN}$ could be recovered from the leaves even after they had received the several washings of alkaline, distilled, and acidulated water (see table 7, p. 481). Similar results are indicated in table 5 (p. 480), where it is shown that HCN could be recovered from mature citrus leaves although they had been exposed to the laboratory air for as long as 15 hours. By the end of the 15-hour period, the leaves had become badly wilted and had lost about 27 per cent of their water content. Further evidence that the HCN penetrates into the citrus tissues is presented in table 11 (p. 489), which shows that $\mathrm{HCN}$ could be recovered from the pulps after the peels had been removed from fumigated whole fruits. These results are specially mentioned because of unpublished statements to the effect that HCN does not enter citrus leaves or fruits but merely adheres to their cutinized surface during the fumigation period of 40 or 45 minutes.

The first group of results given in table 5 (p. 480) were obtained by removing the leaves from the fumigation flask, exposing them to the laboratory air, and stirring them for 1 minute before distilling them to recover the HCN. The question may be raised as to whether all of the $\mathrm{HCN}$ had escaped from the surface of the leaves during such a short period of time. That such a time interval was sufficient is indicated by the fact that the average of the amounts of HCN recovered from leaves treated in this manner was 66.8 per cent (table 5 ), while the average recovered from the leaves that had received the several washings, after being fumigated and before being distilled, was 66.3 per cent (table 7, p. 481).

The results given in tables 10 and 11 (pp. 487 and 489) are expressed in milligrams rather than as percentages. Recovery percentages, calculated on the basis of the total quantity of $\mathrm{HCN}$ added to the fumatorium and the amount recovered from the fruit would be of little value, since a considerable quantity of the HCN was sorbed on the walls of the fumatorium; HCN is known to be strongly sorbed on surfaces of this kind. Furthermore, traces of sodium or other alkaline substances on the walls of the fumatorium would also react with the HCN. Early investigations showed that soda glass could not be used in such experiments.

As has been stated, tests were made, usually at intervals of $2,7,15$, and 30 minutes, in order to determine the relative concentrations of HCN to which the tissues were exposed in the fumatorium during the fumigation period. The maximum decrease in the amount of $\mathrm{HCN}$ in the fumatorium at the time of the 30-minute test, in comparison with that present at the 
time of the 2-minute test, was 14.4 per cent. The average decrease for all fumatorium tests was 8.2 per cent.

Results of unpublished experiments ${ }^{7}$ show that this average of 8.2 per cent is very close to the average obtained when tests were made to determine the amounts of HCN that would be sorbed by the walls, pipes, and other portions of the iron fumatorium when no tissues were present. Therefore only a comparatively small proportion of the decrease in HCN in the fumatorium by the end of the fumigation period was due to absorption by the fruit that was being fumigated. However, computations from the data in table 10 (p. 487) indicate that a given volume of fruit contained from ten to fourteen times as much $\mathrm{HCN}$ as an equal volume of air in the fumatorium. The amounts of $\mathrm{HCN}$ to which the different lots of fruits were exposed, as given in tables 10 and 11 (pp. 487 and 489), are the averages of the tests made during the fumigation period and not the original amounts placed in the fumatorium.

In a preliminary report, Bartholomew and Raby (3) stated that a comparatively large amount of HCN was combined or fixed by substances distilled from citrus leaves in such a manner that it would not react with standard $\mathrm{AgNO}_{3}$. The present investigations have shown that the amounts of HCN fixed by citrus tissues (table 6, p. 481) are not so great as they stated. The reason for the error in the preliminary work was the presence of $\mathrm{H}_{2} \mathrm{~S}$ in the distillate, which prevented the determination of the end point until excessive amounts of $\mathrm{HCN}$ had been added. The placing of $\mathrm{CdSO}_{4}$ in the distillation flask obviated the difficulty encountered in the earlier work because it changed the volatile $\mathrm{H}_{2} \mathrm{~S}$ to nonvolatile CdS.

\section{SUMMARY}

Methods are described for the handling of $\mathrm{HCN}$ in amounts as small as 10 to $15 \mathrm{mg}$ and for the distillation, recovery, and determination of $\mathrm{HCN}$ from citrus tissues.

Hydrogen sulfide from the fumigated citrus leaves and fruits passed over into the distillate and interfered with the determinations of $\mathrm{HCN}$ with standard $\mathrm{AgNO}_{3}$. This trouble was overcome by placing $\mathrm{CdSO}_{4}$ in the distillation flask at the time of making the first (fruits) or second (leaves) distillation.

Tissues of citrus leaves and fruits are already acid, so that only a small amount of concentrated $\mathrm{H}_{2} \mathrm{SO}_{4}$ had to be added to insure the recovery of the HCN during distillation. No destruction of the HCN occurred as a

${ }^{7}$ Lindgren, D. L. Sorption of HCN by the walls of a metal fumatorium. Unpublished material on file at University of California Citrus Experiment Station, Division of Entomology. 1935. 
result of using $\mathrm{H}_{2} \mathrm{SO}_{4}$ of these concentrations, and even better recoveries of HCN were obtained than when the tissues were distilled in the presence of a 2 per cent solution (beyond neutrality) of tartaric acid.

The experimental results indicate that citrus leaves and fruits fix or alter a portion of the HCN during the fumigation period so that it cannot be recovered by distillation. Approximately 85 per cent of the HCN could be recovered from mature leaves and 73 per cent from immature leaves. Less HCN could be recovered from leaves that had been finely ground before being fumigated than from fumigated whole leaves. There was an evident fixation of a portion of the HCN. HCN penetrates into the tissues and does not merely adhere to the surface. This was shown by the tests in which the leaves were thoroughly washed before distillation and by the fact that HCN could be recovered from the pulp of fumigated fruits after they had been peeled.

Aeration tests with mature fumigated leaves showed that the amounts of HCN that could be recovered from them decreased in roughly inverse proportion to the length of time of aeration. Fifteen per cent was recovered from the leaves after 15 hours, but none could be recovered from the fruits after 44 hours.

The amounts of HCN that could be recovered from citrus leaves and fruits were directly proportional to the amounts of $\mathrm{HCN}$ placed in the fumatorium in these tests.

When leaf and fruit distillates which contained $\mathrm{HCN}$ were allowed to stand, some unknown substance in the distillate continued to combine slowly with the HCN so that it would not react when titrated with standard $\mathrm{AgNO}_{3}$.

By the end of the 40-minute fumigation period in the fumatorium, a given volume of the green fruit contained from ten to fourteen times as much HCN as there was in an equal volume of air in the fumatorium.

\section{ACKNOWLEDGMENTS}

Sincere acknowledgments are made to the Division of Entomology of the Citrus Experiment Station for the use of its very efficient experimental fumatorium, and especially to Dr. David Lindgren of that division, who fumigated the different lots of fruit and made the four concentration tests on the $\mathrm{HCN}$ in the fumatorium at each fumigation. 


\section{LITERATURE CITED}

1. Alsberg, C. L., and O. F. Black.

1916. The separation of autogenous and added hydrocyanic acid from certain plant tissues, and its disappearance after maceration. Jour. Biol. Chem. 25:133-40.

2. BARTHOLOMEW, E. T., and E. C. RABY.

1935. Photronic photoelectric turbidimeter for determining hydrocyanic acid in solutions. Indus. and Engin. Chem., analyt. ed. 7:68-69.

3. Bartholomew, E. T., and E. C. RaBy.

1936. The recovery of hydrocyanic acid from fumigated citrus leaves. Jour. Biol. Chem. 113:655-60.

4. Совв, A. W., and J. H. Walton.

1937. The reaction of hydrocyanic acid with sulfuric acid and phosphoric acid. Jour. Phys. Chem. 41:351-63.

5. Krieble, V. K., and A. L. Peiker.

1933. The hydrolysis of hydrogen cyanide by acids. Jour. Amer. Chem. Soc. $55: 2326-31$.

6. Morris, S., and V. G. LiLly.

1933. Distillation of hydrocyanic acid from sulfuric acid solutions. Indus. and Engin. Chem., analyt. ed. 5:407-8.

7. Pagel, H. A., and W. Carlson.

1932. The accurate determination of cyanide by distillation from sulfuric acid solutions. Jour. Amer. Chem. Soc. 54:4487-89.

8. SсOTT, W. W.

1925. Standard methods of chemical analysis. 4 th ed. 2 vol. (See specifically vol. 1, p. 509.) D. Van Nostrand Co., New York, N. Y.

9. Sinozaki, Heima, R. Hara, and S. Mitsukuri.

1926. The vapour pressures of hydrogen eyanide. Tôhoku Imperial Univ. Tech. Rept. 6:157-67.

10. Viehoever, A., C. O. Johns, and C. L. Alsberg.

1916. Cyanogenesis in plants. Studies on Tridens flavus (tall red top). Jour. Biol. Chem. 25:141-50. 
